
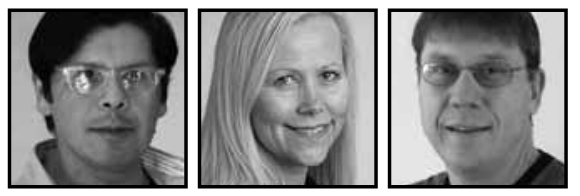

\title{
Nurturing Creativity and Professional Learning for 21st Century Education: ResponsiveDesign and the Cultural Landscapes Collaboratory
}

\author{
Ralph A. Córdova Jr., University of Missouri-Saint Louis \\ Kristiina Kumpulainen, University of Helsinki \\ Jeff Hudson, Alton High School in Southern Illinois
}

\section{ABSTRACT}

This study examines events within a CoLab1 3RDSpace: Summer Leadership Institute on Creativity \& Innovation. The analyses are organized into two telling cases and reveal how participants develop a shared understanding of ResponsiveDesign, CoLab's theory of inquiry and innovation. Drawing on an interactional ethnographic perspective, the analyses make visible the ways in which concepts of space, language, creativity, and innovation complement one another to form ResponsiveDesign as a powerful approach for educators in any setting to transform their ordinary places into extraordinary spaces for creatively confident learning.

Few ideas emerge fully formed. Instead, innovators often try things out and then quickly adjust them in the light of experience. Tinkering seems to play a vital role in all kinds of innovation, involving trial and error, hunches, and experiments that only in retrospect look rational and planned. (Johnson, 2011, p. 151)

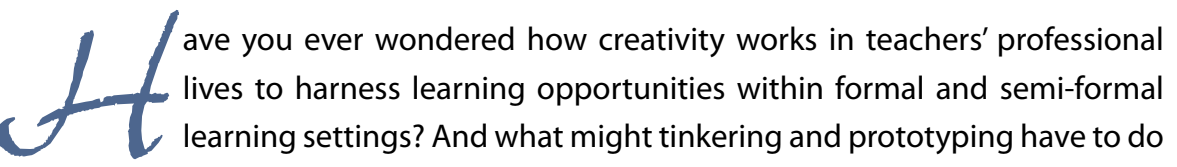
with how teachers develop a shared language and theory to help them collaborate 
and thrive within diverse learning settings? Questions around how creativity and innovation can be harnessed, to transform how we think of and design learning experiences, focuses the work we do as the Cultural Landscapes Collaboratory (CoLab, www.ourCoLab.org). The CoLab is a transdisciplinary community of teacher-researchers concerned with 21 st century education and learning, asking the bigger question: how can schools and non-school settings become innovation spaces where knowledge is no longer just stored and consumed but rather constructed and innovated upon within and beyond the school setting?

In this article, we share with you our theory of innovation and action called ResponsiveDesign. Although grounded in and arising out of over eight years of ongoing teacher-research projects, this study situates our explorations and insights against the backdrop of a five-day institute from the summer of 2012, involving eight American universities and three museums, called the 3RDspace Summer Leadership Institute on Creativity \& Innovation. We examine the ways we came to develop a shared theoretical and pedagogical understanding of ResponsiveDesign, and, the ways we can apply it to our teaching practices in order to innovate them. The participants were National Writing Project (NWP) affiliated teacher-researchers from across the United States, museum educators, graduate students, and one literacy coach from a school district. $^{2}$

\section{The 3RDspace Summer Leadership Institute on Creativity \& Innovation}

The experientially and theoretically grounded institute had two mutually informing goals. The first focused on harnessing the CoLab's theory of action called ResponsiveDesign in order to unpack how we think about and understand what counts as innovative and creative leadership. The second goal was to harness ResponsiveDesign in order to support NWP, Museum, and School District leaders to explore, envision, and enact creativity-centric partnerships among local formal and semi-formal learning settings.

Thus, our 3RDspace institute goals were situated within the nexus where formal and semi-formal learning settings overlap: namely schools and National Writing Project sites interacting with and learning from museums and library settings. From this overlapping "cultures" perspective, we conceived of our institute as being a "third space," or state of in-betweenness. In this space, participants could explore each other's individual local challenges and prototype radical solutions while concurrently testing ResponsiveDesign in St. Louis locales, making them cultural landscapes for learning that led to powerful insights. From this perspective, the name 
3RDspace held significance for the group. The number three represented the three E's in ResponsiveDesign's methodological processes: Explore, Envision, Enact, whereas the $R D$ represented ResponsiveDesign. Thus the $3 R D$ space connotes the making of learning spaces by harnessing ResponsiveDesign as a theory of action and innovation.

\section{Our Work's Theoretical Significance and Practical Applications}

Although we view our conceptual approach to professional learning as innovative, the need for this kind of work is not new. In the last decades of the 20th century, educational scholars have assisted us to conceive of learning as situated phenomena that is socially constructed within formal school settings (Anderson-Levitt, 2002; Dyson, 1993; Dyson et al., 1995; Gumperz \& Cook-Gumperz, 1986; Green \& Meyer, 1991; Heath, 1983) and outside of school settings within the larger constitutive communities of practice (Córdova, 2008; Lave \& Wenger, 1991; Wenger, McDermott, \& Snyder, 2002) and families' cultural ways of knowing and being (Moll, Amanti, Neff, \& Gonzalez, 1992; Yeager \& Córdova, 2010) with which schools interact. Thus, accounting for the interactive nature of in-school and out-of-school learning relationships has been the source of robust scholarship in the last four decades, and that focus is grounded in an even longer research tradition dating back to philosophers and scholars like John Dewey (1916) and John Cotton Dana (1917).

Since the beginning of the last century, scholars have been conceptualizing the role that experience plays in the processes of teaching and learning inside (Dewey, 1916; Heathcote \& Bolton, 1994) and outside (Dana, 1917; Montessori, 1969) of schools. Further, how we come to think about school as participatory learning spaces has been influenced by theorists like Paulo Freire and Loris Malaguzzi who, following in the progressive education tradition, pushed us to think critically about how the pedagogies we as educators construct contribute to the awakening of critical consciousness - or hinder it. Thus, a tradition of critical pedagogies has long assisted educators and researchers in formal settings with ways to conceive of schools beyond simply places where knowledge is replicated but where new cultures can be invented (Córdova, 2008, 2010; Freire, 1998).

Knowing is one thing, and we know so much about how learning communities are constructed and the consequences for their particular ways of knowing and being. Yet, doing is another. Though rich in empirical knowledge, in the fields of teacher and museum education we seem to know very little about how to actually harness empirical research, ripe with insights on how learning cultures emerge, and harness those insights to nurture and grow innovative learning communities in our 
own backyards. It is this very disconnect between theory and practice, within formal and semi-formal learning settings, that the CoLab has begun to bridge.

In any sociocultural setting, there are elements that challenge educators' creativity in designing extended spaces for learning that connect school with communities and students' learning lives. For example, in the US "teaching for the test" easily narrows down teachers' freedom to design 21 st century learning opportunities for their students that build bridges across different communities. Further, teachers begin to narrow (Achinstein \& Ogawa, 2006; Allington, 2001; Córdova \& Matthiesen, 2010; MacGillivray, Ardell, Curwen, \& Palma, 2004) the educational potential semiformal learning spaces have not only for their students, but also for themselves. In fact, Crocco and Costigan (2007) have argued that what has been called the narrowing of what counts as curriculum (e.g., Dillon, 2006)—which they expand to include the impact of mandated, prescribed curriculum that "frequently limits pedagogical options" (p. 514) - has meant that teachers in many schools "often find their personal and professional identity development thwarted, creativity and autonomy undermined, and ability to forge relationships with students diminished" (p. 514).

Globally, both formal and semi-formal learning institutions such as museums and libraries are struggling to respond to 21 st century learning demands with "one size fits for all" approaches. These locations whose pedagogical understandings developed in a previous century responding to particular demands of long ago, are now seeking new approaches relevant to the new challenges (Córdova, 2008; Murawski \& Córdova, 2012). It seems harder than ever for teachers and students to create learning communities (Dixon \& Green, 2009; Lave \& Wenger, 1991; Santa Barbara Classroom Discourse Group, 1992a, 1992b) that honor students' and teachers' lived experiences as funds of knowledge (Moll, 1994; Moll et al., 1992) to build upon as readers and writers-and researchers.

Thus, we are presented with a daunting task as school and museum based teacher-researchers to learn how to mitigate the disconnect in cultural expectations between teachers as they learned to construct a professional learning community, and between teacher learning communities and the museum environment with its own cultural expectations. As the CoLab, we seek to create sustainable professional interdisciplinary learning spaces to nurture and become the researchers of diverse cultural landscapes, seeking answers to the questions that emerge from our everyday work. 


\section{Our Inquiry}

While space prohibits a reporting of the comprehensive analyses completed of the five-day institute, our piece is organized as an exploration into a slice of our work, and, concludes with an invitation for collaboration. Questions leading our inquiries:

1. How do teacher-researchers and leaders move from individual to collective understandings of ResponsiveDesign as a theory of action and inquiry? Related to this question, we explore how teacher-researchers and leaders harnessed ResponsiveDesign to explore, envision, and enact a cultural practice called the Artifact Box as an inquiry into teaching practices.

2. How does how we think about space and struggle shed light on how teachers grapple with complex ideas leading to insights about teaching, learning, and leadership? Related to this question, we examine how the teacher-researchers and leaders created and entered transformative spaces for learning when they engaged in community-based art making alongside a professional communitybased artist, Takashi Horisaki.

First, we begin by discussing the theoretical and methodological considerations undergirding our work including data and setting. Second, we will discuss what the CoLab is and what its theoretical roots are as an innovative transdisciplinary community of learners, including defining our theory of action called ResponsiveDesign and how it works. Third, our analyses make visible the creativity-centric theoretical routes that CoLab teacher-researchers have journeyed by describing the fiveday $3 R D$ space institute. Against this backdrop, we organize our two analyses in what Mitchell (1984) calls telling cases, which serve as a methodology out of which theory, concepts, and hypotheses can be drawn, leading to further research. We conclude with an invitation for international collaboration with the CoLab.

\section{Theoretical and Methodological Traditions That Orient Our Study}

Our views are grounded in an interactional ethnographic perspective (Santa Barbara Classroom Discourse Group, 1995) that lets us understand classrooms and learning settings as cultures (Santa Barbara Classroom Discourse Group, 1992a, 1992b) and knowledge as situated and socially constructed. We expand our view by 
drawing from the field of museum learning (Hein, 1998; Falk \& Dierking, 2000; HooperGreenhill, 2007). From these perspectives, our study reveals how teacher-researchers can explore issues pertinent to constructing creativity and innovation-focused learning communities in schools and with museums by drawing on theories from anthropology (Frake, 1977; Gumperz \& Cook-Gumperz, 1986; Spradley, 1980), critical discourse analysis (Fairclough, 1992; Ivanic, 1994), and literary theory (Bakhtin, 1986).

\section{Data and Setting}

The data examined in this study were collected during the five-day Summer Leadership Institute on Creativity \& Innovation, July 9-13, 2012 in St. Louis. Data records include video footage, participant work samples, and field notes. The authors collaboratively collected them across diverse learning settings where the institute took place: two art museums, a chess museum, and a fine arts gallery. Ralph, first author, is a university-based researcher. He is Latino, of native Mexican-Indian and Spanish cultural heritage. Kristiina, second author, is a Finnish educational researcher. Third author, Jeff is a white man, and high school English teacher-researcher. Ralph and Jeff co-developed the 3RDspace summer institute along with fellow CoLab members: Michael Murawski, Director of School Services for the Saint Louis Art Museum; Patricia Swank, high school English teacher; Dawn Jung, university instructor, and Ann Taylor, university researcher. These CoLab leaders and participants are from the eight National Writing Project sites and two art museums totaled 25; nineteen women and six men.

\section{The CoLab's Roots and Routes}

To conceptualize the dynamic nature of the CoLab's cultural roots and routes presented in this article, we invoke the concept of morphogenesis (Turing, 1952) and emergence (Johnson, 2001) to help us understand the organic and spontaneous processes inherent in the moment-to-moment and over time nature of how humans socially construct learning cultures at the ground level. Turing posited that complex systems have origins that emerge organically from the bottom-up, not authoritatively from the top-down. Johnson argues that organized complexity emerges over time out of seeming chaos giving shape and physicality to phenomena.

CoLab's origins can be traced back to an idea planted in 2004 in an innovative and synergistic interplay between diverse National NWP sites and the Santa 
Barbara Classroom Discourse Group (SBCDG, 1992a, 1992b). At that time, Ralph, the first author, was a bilingual third grade teacher and had just completed his Ph.D. He first conceived of the Collaboratory idea as a space for NWP teacher-researchers to explore their classroom and larger communities as cultural landscapes for learning. Complementing these roots, the routes of action that CoLab members have taken have led them to collaborate internationally with the Learning Bridges research network (www.oppimisensillat.fi) located in Finland at the University of Helsinki, Department of Teacher Education (see also Kumpulainen et al., 2011). In 2005, Finnish researcher Dr. Kristiina Kumpulainen became a CoLab member, leading the group to collaborate internationally with Finnish teachers, teacher education and interdisciplinary research networks on learning.

From this local-to-global, recursive, school-based learning interplay, CoLab's routes further articulated themselves in the form of global teaching and research partnerships between museums and informal community-based institutions with a shared focus on interdisciplinary professional learning (Córdova \& Murawski, 2010). Because we are transnationally located, we bring our respective local sociocultural knowledge of educational policy and practice to our work. It is through this synergistic and dynamic collaboration that we develop shared understandings of the particular educational challenges facing educators in both American and Finnish settings.

In 2009, CoLab began to interact with and learn from Stanford University's d.School and faculty. The d.School is an interdisciplinary learning hub, housed at Stanford, where undergraduate and graduate students work together across all disciplines. The d.School draws on a design-thinking approach, an ethnographic process that invites users to generate ideas, insights, and innovation. Our work with the d.School enabled us to name and articulate our own theory of innovation and action, which we named ResponsiveDesign (discussed in the next section).

Thus, CoLab's morphogenesis reveals a synergistic concept of action that is informed by seeming disparate places and diverse people, disciplines, and ideas. Our members self-select to collaborate towards a shared goal of building to learn and to innovate upon what is presently known in our learning settings. Building upon its human-centered ethnographic and language centered origins, however, the routes that the CoLab has taken reveal an image of an organic and dynamic self-learning and self-teaching organism without one particular physical space. 


\section{What Is ResponsiveDesign?}

Our ResponsiveDesign theory of action grew out of our collective efforts to notice and name the logic-of-inquiry we used in our teacher-researcher work. Therefore, we sought to name our process with language that would account for our ethnographic approach of interacting with and learning from others. In this way our process could be accessible to educators beyond our local setting. The ethnographic practice of "deep diving" into situations helps us to respectfully surface people's needs (Responsive), while the field of art and design guides us to create prototypes (Design) of practice to be tested in the field.

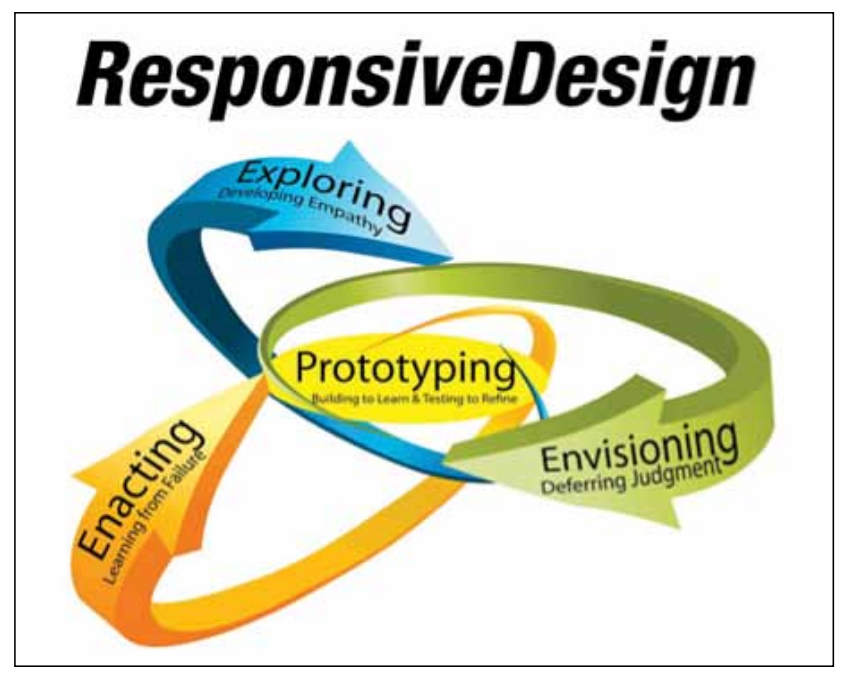

Fig. 1: ResponsiveDesign

ResponsiveDesign's epistemology posits that people are natural theory-makers and theory-testers whose works foster in them innovator growth mindsets that can become habits of mind. Through the multiple iterative cycles of rapid prototyping used in its work, by exploring to develop empathy, envisioning by deferring judgment, and enacting in order to learn from failure, participants come to conceptualize their teaching practices as cultural technologies that can be harnessed and innovated upon.

CoLab's theoretical ethnographic and language-centric roots are at the heart of ResponsiveDesign's "DNA": Dive \& Document, Notice \& Name, Analyze \& Announce. This play on words, for us, helps us remember our theoretical cultural heritage and serves to focus ResponsiveDesign's purpose as a generative, human-centered, and creativity-harnessing theory of action and innovation. 


\section{Examining the 3RDspace Summer Institute}

The National Writing Project's Digital Is Initiative supported eight NWP sites representing diverse universities and communities, to collaborate with the CoLab to enact the 5-day institute. NWP's Digital Is Initiative is funded by the John D. and Catherine T. MacArthur Foundation's Digital Media and Learning Initiative. NWP site leaders and museum educators brought their site-based innovation problems and educational quandaries to this more global space, thus creating a "third space," harnessing ResponsiveDesign, where they were to learn innovation-yielding technologies that CoLab leaders would guide them through.

Therefore there is a double-meaning in the concept being constructed known as $3 R D$ space. One meaning resides in the number 3 representing explore, envision, enact with $R D$ representing ResponsiveDesign. The second meaning, is a theoretical one, developed by scholars in the last two decades to help us to understand the role that struggle, space, and states of in-betweenness play to help us transform and grow (Anzaldúa, 1987, 1993; Córdova, 2008; Franquíz, 1999; Gutierrez, Baquedano-López, \& Tejeda, 1999).

Franquíz (1999) drew on Anzaldúa's (1987, 1993) conceptualization of Nepántla, a Náhuatl word meaning a non-physical state of in-betweenness. People create Nepántla as they navigate within and across physical and non-physical borders. Nepántla describes the transformative nature of what happens for individuals and collectives as they simultaneously shape and are shaped by their environments. Across the overlapping spaces where students, teachers and community-based artists live and work, they struggle with complex ideas, experiences, and issues. For example, in the context of a fifth-grade classroom learning about the Holocaust, Franquíz (1999) made visible how students assisted each other to navigate the complex terrain of these social issues and how they applied understandings of inequity and racism to their everyday lives.

On day one, July 9, 2012 the twenty-five participants began the fiveday experience at the St. Louis Chess Museum Hall of Fame at 9:30 a.m. In Table 1: 3RDspace Daily Events, an overview of each day's focus is provided. The analyses in our two telling cases are of events from Day 1, highlighted in green, and Day 2, highlighted in orange. 
Table 1

3RDspace Daily Events and Units of Analysis

\begin{tabular}{|c|c|c|c|c|}
\hline $\begin{array}{l}\text { Day } 1 \\
\text { July } 9\end{array}$ & $\begin{array}{l}\text { Day } 2 \\
\text { July } 10\end{array}$ & $\begin{array}{l}\text { Day } 3 \\
\text { July } 11\end{array}$ & $\begin{array}{l}\text { Day } 4 \\
\text { July } 12\end{array}$ & $\begin{array}{l}\text { Day } 5 \\
\text { July } 13\end{array}$ \\
\hline $\begin{array}{l}\text { Patti harnesses RD in an } \\
\text { inquiry into My Practice } \\
\text { (iIMP) with Ralph as } \\
\text { ThinkingPartner }\end{array}$ & $\begin{array}{l}\text { Dive into painting bulling } \\
\text { with latex with artist } \\
\text { Takashi Horisald } \\
\text { Groups huddle to paint } \\
\text { colored latex on stone } \\
\text { facade in layers with } \\
\text { cheese cloth. } \\
\text { Group peels latex } \\
\text { Lunch }\end{array}$ & $\begin{array}{l}\text { Meet at Saint Louis Art } \\
\text { Museum } \\
\text { Quick-Write: "On Monday. } \\
\text { I used to thirk, now, I am } \\
\text { wondering? } \\
\text { DesignChallenge harnessing } \\
\text { ResponsiveDesign: 'the } \\
\text { Ideal Vehicle' } \\
\text { Unpack DesignChallenge } \\
\text { experience } \\
\text { Lunch }\end{array}$ & 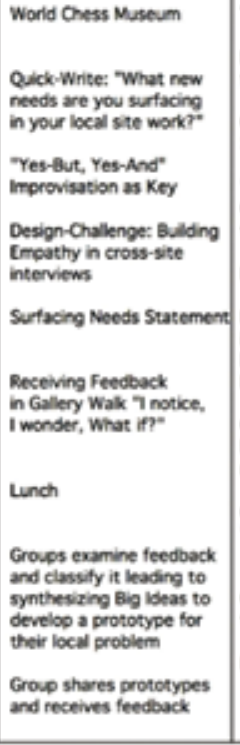 & $\begin{array}{l}\text { Tavem of Fine Arts } \\
\text { Imorovise making a dragon- } \\
\text { fly, octopus and helicopter } \\
\text { Quick-Write: "What is a } \\
\text { 36Dspace?" } \\
\text { "What We Do Best" Ben } \\
\text { Garcia article as theory } \\
\text { to re-see our week together } \\
\text { Lunch } \\
\text { Ba Donivs guides group } \\
\text { in creativity exercise from } \\
\text { his new book "Thought } \\
\text { Revolution" } \\
\text { Quick-Write: "As a site } \\
\text { leader, now I realize I } \\
\text { need to...What if?" } \\
\text { Group Crows Sources } \\
\text { "What-if" statements }\end{array}$ \\
\hline
\end{tabular}

\section{Telling Case One: Unpacking and Harnessing ResponsiveDesign as Shared Theory of Action and Inquiry}

At 10:30 a.m. Ralph, a 3RDspace leader, asked each participant to do a bit of writing, "as an individual, please take just one minute, and I'll time you, to jot down in your writer's notebooks everything that comes to mind when you hear the word 'explore."' After a minute, Ralph asked the participants to pair up with particular directions: "Think of the words you are about to share with your partner as your DNA, and if you hear an intriguing association from your partner, feel free to steal it and add it to your list." The pairs were given two minutes to share with each other, and then were called back to attention as a whole group. Ralph repeated the process again with them two more times, this time asking them to entertain the word "enact" and then the word "envision."

After the repetitive process of unpacking individually and then sharing in pairs, their understandings of "explore, envision, and enact," Ralph asked the group to consider a new challenge as he guided the group to consider the purpose for why we share ideas with one another. Table 2 contains a transcript of his framing directions in message units. 


\section{Table 2}

\section{Framing What Counts as Explore, Envision, Enact}

\begin{tabular}{l|l} 
ACTOR & MESSAGE UNITS \\
Ralph: & \\
Science writer \\
Steven Johnson \\
talks about \\
the coffee houses \\
of eighteenth century \\
England \\
as being \\
innovation places \\
and the birth place \\
of the Enlightenment. \\
He tells us \\
for much of Europe's earlier history, \\
people drank ale because \\
water was dangerous. \\
Then tea and coffee became available, \\
and people no longer drunk, \\
were buzzed on caffeine sharing ideas \\
in these cramped locations. \\
He calls coffee houses as \\
the place where ideas go \\
to have sex \\
with each other
\end{tabular}

As Ralph guided each pairing to consider itself as an "organism" with its particular understanding of explore, envision, and enact as its working and viable "DNA," he opened up for the participants metaphorical ways to understand how ideas are shared that may lead to new ideas to emerge. When he guided groups to make a larger organism of four people-with each pairing sharing with the other its understandings of those three words-pairings acted as nodes within networks and their cross-pairings led to networks to become circuits of understandings. 
After five minutes, he interrupted the groups to instruct them they had a challenge before them. In the next 10 minutes, they were to take their shared understanding of explore, envision, enact, and theorize, in a visual representation, the ways those three sets of understandings work together. Five minutes later the four groups of four participants were asked to share with the larger group what they theorized the relationship to be among explore, envision, and enact.

In Figures 2 and 3 we see the four groups' articulations of explore, envision, and enact. Group One draws on a holistic and natural metaphor to depict its understanding of ResponsiveDesign as a dynamic cycle of life with energy sources, predator, and prey. Group Two draws on a metaphor from earth science depicting ResponsiveDesign's explore, envision, enact as an energetic tornado with "perspectives and ideas that are big and small." The tornado picks them up and throws them out." This group described the force of new ideas to change existing models and perspectives.

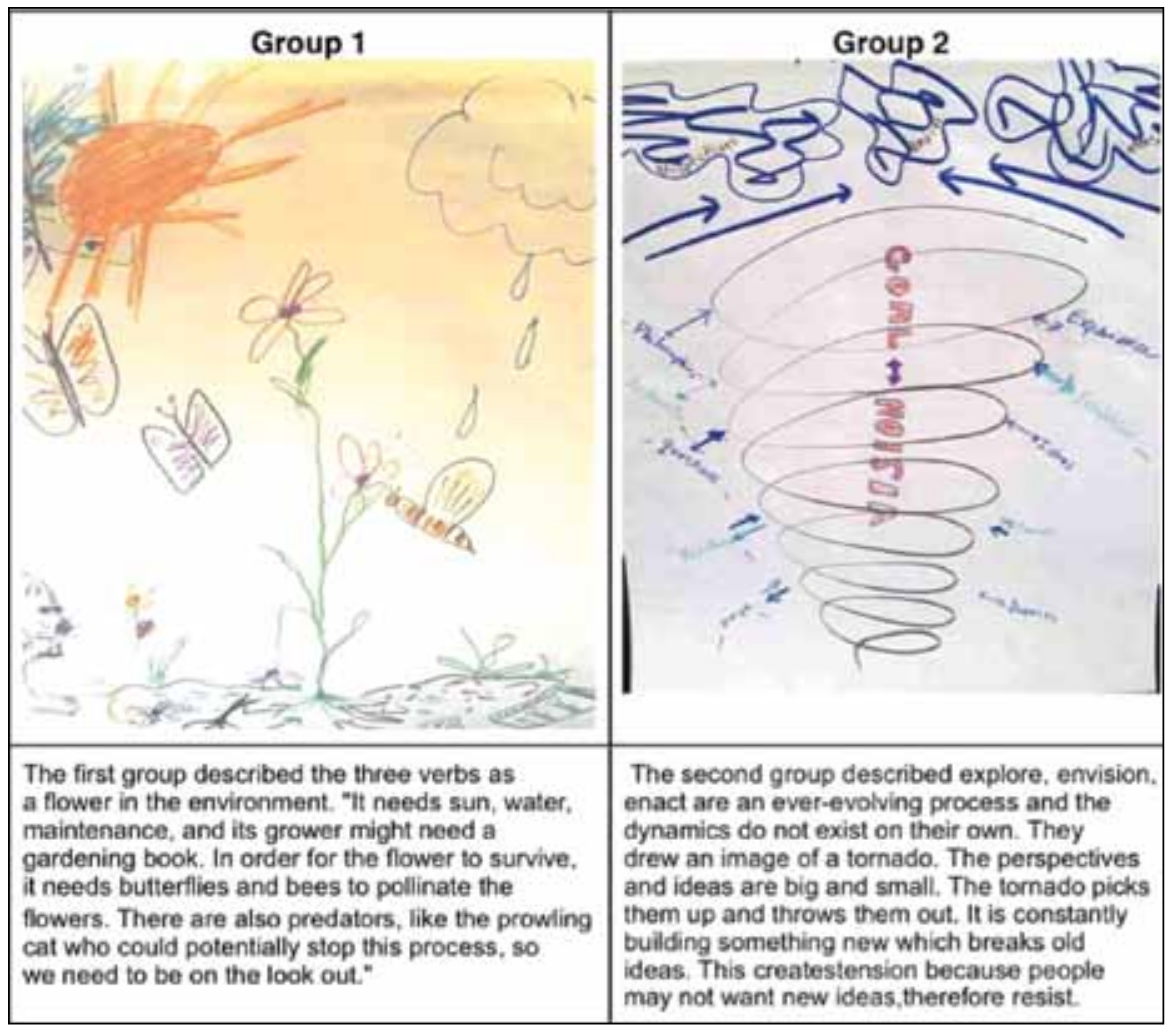

Fig. 2: Groups 1 and 2 make visible shared understandings of ResponsiveDesign 
Group Three draws upon a cooking metaphor likening the development of new ideas akin to baking bread from onset to loaf. They discussed the seeming disparate nature of the individual ingredients, and, when energy is applied, the result is an altogether molecularly different product: bread. Group Four drew upon the scientific notion of the "Big Bang" to articulate that any inquiry has the potential to take one to unexpected understandings, all within the realm of what is possible to be known within the laws of physics and human understandings of the universe.

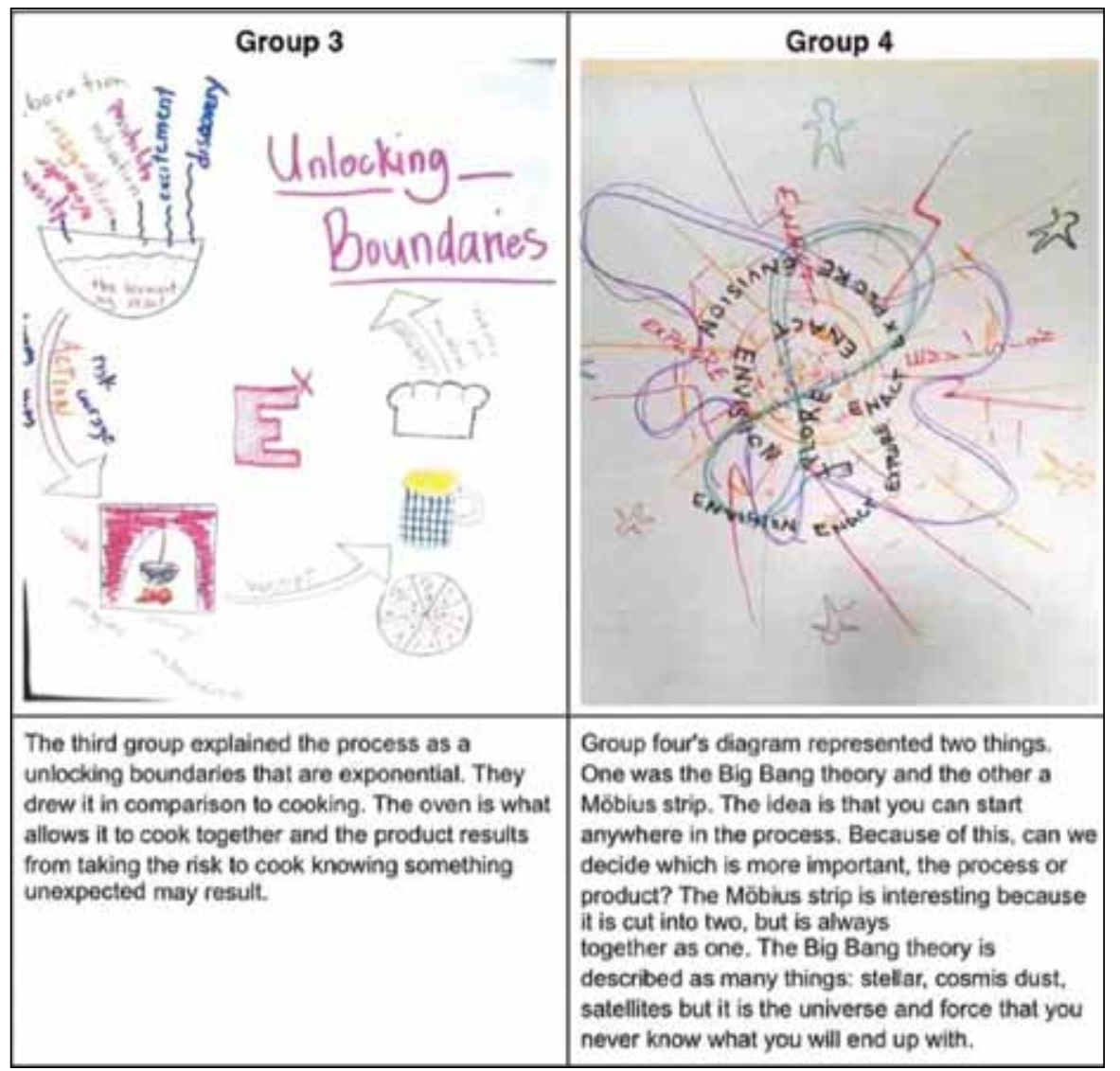

Fig. 3: Groups 3 and 4 make visible shared understandings of ResponsiveDesign

When the individual members were afforded opportunities to unpack what each word, "explore, envision, enact," represented to them, they were drawing upon their individual experiences to make present, or visible, any associations with those words in light of what the prospective 3RDspace institute had the potential to become. When the individuals became pairs, three times, throughout the first part of the "unpacking" exercise, they acted as individuals-within-a-collective of knowers. After the exercise, 
each pair was asked to make sense of its paired understanding of those three verbs that constitute ResponsiveDesign. By having had this opportunity to engage as both individual and an individual-within-a-collective (Souza-Lima, 1995) pair, both participants drew upon their individual knowledges to create a shared knowledge.

By harnessing the semiotic processes of inscribing a mediated, negotiated, and shared understanding of explore, envision, enact into a metaphor, each foursome made visible to the larger group its temporal understanding of ResponsiveDesign. As each group shared, as an individual cluster of knowledge, the collective understanding of what could count as explore, envision, enact was socially constructed in real-time.

\section{Harnessing ResponsiveDesign to Become "Archaeologists" of Each Other's Lives: The Artifact Box}

After this public display of individual and shared knowledge of ResponsiveDesign, the group had a ten-minute break after which Patti, a CoLab leader and participant, would ask the group to harness ResponsiveDesign in a different way, this time as an inquiry methodology as she engaged all members in a lesson. Patti recasted a typical lesson, called the Artifact Box, as an "Inquiry Into My Practice" (IIMP), which she wanted to both use to help facilitate community-building among the participants, and, she also wanted the participants to help her critically examine the lesson/IIMP after it concluded. For the CoLab, this IIMP process involves a Pre-Brief conversation between the lead teacher and a "Thinking-Partner." Then the lesson is enacted. The IIMP process is concluded with a public reflective conversation between the lead teacher and the Thinking-Partner about what took place during the lesson.

The Artifact Box is a teaching and learning technology that involves participants collecting items that represent themselves, placing them in a box or bag, and, then setting them up, in a curated approach, in a shared space that will become a "gallery." Each person then walks around silently in the gallery space, interacting with the curated objects that colleagues assembled for them, leaving feedback guided by "I noticed..." and "I wonder..." on sticky notes placed on the items. After about fifteen minutes of noticing and wondering, all participants return to their own Artifact Box, and read through the noticings and wonderings. They are then to select one of the most compelling pieces of feedback and engage in a 15-minute, sustained, moment of writing to address that noticing or wondering. To conclude, participants pair up and read their writing, and, then aloud to the whole group. 


\section{IIMP pre-brief.}

During the Artifact Box Pre-Brief, Patti would harness ResponsiveDesign's explore, envision, enact iterative cycles with a colleague, Ralph, as her"Thinking-Partner" to critically examine the Artifact Box process. At the CoLab, a Thinking-Partner helps the lead teacher, about to enact a prototype of her practice, to verbally articulate aloud what she will explore in the lesson, what she envisions will occur, and, when enacted, what she wants learners to walk away knowing and caring about. The IIMP's "Pre-Brief" conversation took place in front of the participants with whom she would shortly enact her prototype of practice. This was a process of building empathy, of listening. Acting as Patti's thinking partner, Ralph's role is crucial; he served as the empath. He guided the pre-brief through a process of noticing: "So I heard you say..." and questioning, "I wonder..." Ralph drew out and makes visible for everyone, Patti's expertise, her locally held wisdom.

\section{Enacting the IIMP.}

While enacting her IIMP, Ralph took notes, while Patti guided the group through an hour-long exploration of each other's artifacts as lived experiences, interrogations, and wonderings of those artifacts, which then led to sustained writing in response to those artifacts. In Figure 4, we see teacher-researcher, Jeff's (third author) Artifact Box containing fishing fly-ties, pictures of his daughters, and National Writing Project paraphernalia. As the artifact-box inquiry was enacted, each participant dove in, suspending judgment. Each learner attended fully to what unfolded, feeling safe in the knowledge that part of the process would involve an opportunity to debrief, to envision possibilities, to appropriate the learning for his/her own purposes and contexts.

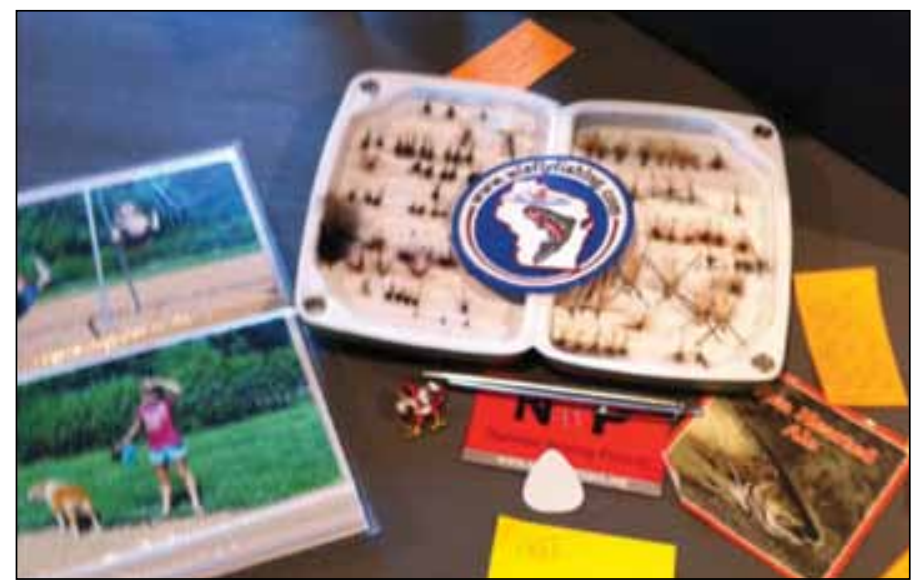

Fig. 4: Jeff's Artifact Box 
Each member of a learning community was valued as a knower. Each member was supported and pushed to move along the continuum from less expertise to more expertise. In taking the lead, Patti allowed all learners to envision themselves sharing and inquiring into practice.

\section{Debriefing the IIMP.}

During the IIMP Debrief, Patti and Ralph reflected upon what they both noticed during the learning experience. She noted that this application of the Artifact Box was to support diverse people from across the country to get to know each other, while simultaneously demonstrating how the Artifact Box technology worked as an Inquiry Into My Practice (IIMP) using ResponsiveDesign as a theory of inquiry and innovation.

After the debrief, Patti asked participants to write reflectively about the entire experience. This reflection written in Jeff's notebook moments after Patti's IIMP provides us with insight about how participants were making sense of and connections with the experience:

What we just experienced actually started several days ago when we were asked to assemble the artifacts - symbolic representations of identity, of experience, of memory. Then, via Patti's instructions, we let our identities ripple out and interact with others, strangers who are less strange now.

Via our [sticky note] noticings and wonderings we conjured stories-powerful stories which reveal connections, which now constitute the fabric squares of this new quilt (the quilt metaphor here is the direct residue of another Artifact Box containing a quilt made for students), Patti guided us from individual to community member and back again.

—Jeff's journal entry, July 9, 2012

Looking back at this event, we notice the intentionality of Patti's leadership. It was not an accident that another teacher's Artifact Box became a metaphor that Jeff employed to make sense of the experience. Patti had guided the participants to interact with one another's identity, to slip in and out of one another's stories. We, thereby, were both shaping and shaped by one another. We co-constructed this space for literate action and learning.

The transparency of Patti's leadership, the careful exploring, envisioning, and enacting allowed us to fully attend to one another. We were given space to notice 
and wonder. We were given space to be the expert, to be the storyteller, as an attentive and supportive audience solicited our stories from us. Finally, we were guided back to ourselves and given space to wrestle with the "So What?" of the experience, given space to envision a future for the experience both literally and figuratively.

This process of harnessing ResponsiveDesign to tackle challenges bridging formal and semi-formal learning settings ensued across the 3RDspaces' five days. By Friday, day 5 of the institute, teacher-researchers had become confident navigators of seemingly disparate cultural landscapes of museums and community settings, by exploring, envisioning, and enacting shared inquiries into whose knowledge counts and further refined their individual inquiries and questions to take back to their respective sites. In this way, teacher-researchers were supported to become teacherleaders as they would return home and guide others to unpack and then harness ResponsiveDesign as a prototyping approach to teaching and learning.

\section{Telling Case Two: Constructing Spaces for Struggling With Complex Ideas}

A powerful example of ResponsiveDesign's "Explore: Developing Empathy" and the transformative role that space can play in our learning was made visible to us on Day 2 of our time together that week. Community-based artist Takashi Horisaki invited teachers to grapple with seemingly foreign concepts of performance art that document cultural settings. He helped the group engage in his artistic process of making latex castings of architectural features of buildings near the Contemporary Art Museum. Over cocktails and dinner the night before there were playful and coy hints at what the day would bring. Participants knew it would involve latex, but were given little more. This ambiguity of the day's events asked participants to rely on their unpacking of ResponsiveDesign, asked them to understand the work as an exploration. As such, they exercised their empathy "muscles." They depended upon the support of this emerging community of learners. Further, as a metaphor for classroom practice, Horisaki's work with teacher-leaders at the art museum challenged certain conventional wisdom - the convention of spelling out lesson objectives ahead of time, of providing copious background notes and information prior to any exploration, for example.

In addition to the cognitive ambiguity of "the lesson," the day promised physical challenges as well. The blazing sun and forecast excessive heat warnings had folks slathering on sunscreen, hydrating vigorously, and devising all sorts of shade from hats to canopies and tarps. Direction from Takashi and his aides was sparse. 
Participants were given a paintbrush, cheesecloth, and a cup of pigment-shaded latex and directed to find a surface to begin coating.

Participants settled into clusters working together on shared parts of the building (See Fig. 5, Picture A). Teachers began discussing and sharing. Discussions ranged from personal stories of family and summers to the sharing of work and research interests. Takashi, the artist, often initiated conversation by sidling up to an isolated or quiet painter and asked questions. A couple of things happened in these moments. Diverse and individual experiences began to ripple out, to both shape and be shaped by the community. In addition, Takashi was able to demonstrate various latex casting techniques while each artist was engaged in the very process. As folks talked and imitated, this knowledge spread through the community.

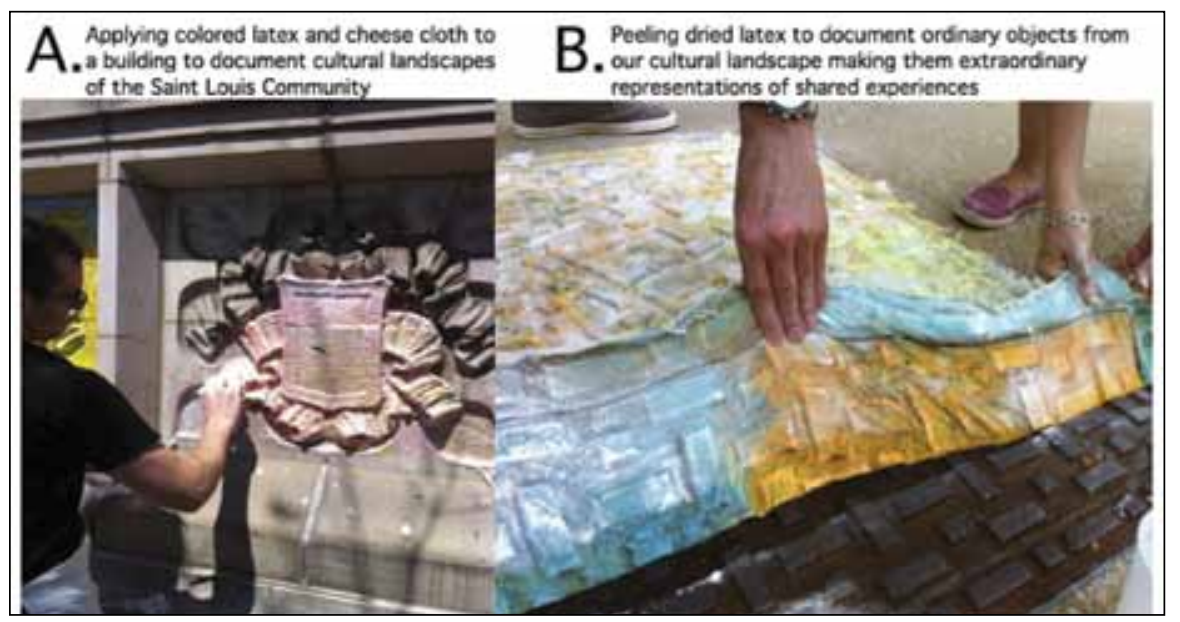

Fig. 5: Documenting our cultural landscapes with latex

Once settled in ambiguity, teachers actually began to attend to what was before them. Expectations and questions about "what is the purpose? What are we doing? What's the significance?" all receded into the background as an intensive 2-hour "doing" phase emerged. In pushing aside preconceived notions and expectations of educational purpose, participants created a state of in-betweenness and thus enacted Nepántla, or the 3RDspace, into being.

Within the span of two hours, the teacher-leaders' castings had dried and then began the process of peeling away the latex (Fig. 5, Picture B), revealing a mold of the negative spaces from various parts of the building and sidewalk. Artists marveled 
at the surprising and colorful castings - surprised as if they were an unexpected gift, a result of their labor. Each cluster of teacher-leaders emerged anew as community artists whose process and product represented the art-as-meaning-making experience.

After lunch, the day's experience ended inside The Contemporary Art Museum. The task: to make sense of the "what happened" earlier in the day. First, a Quick-Write summarized the varied individual experiences of the day: "What did we do with that building today... what just happened?" The group discussed, what came to be called the "So What?," of the day's experience. Horisaki shared with the group his process of developing his art-making techniques stemming from his childhood in Japan, where he had experienced the consequences of rapid city-growth that led to the loss of historical cultural landscapes. He developed a passion for documenting city landscapes alongside city dwellers to tell the "hidden stories" of the city.

These teacher-leader/artists then had an opportunity to explore Horisaki's installation at the Contemporary Art Museum documenting elements of St. Louis' architectural cultural landscapes (see Fig. 6).

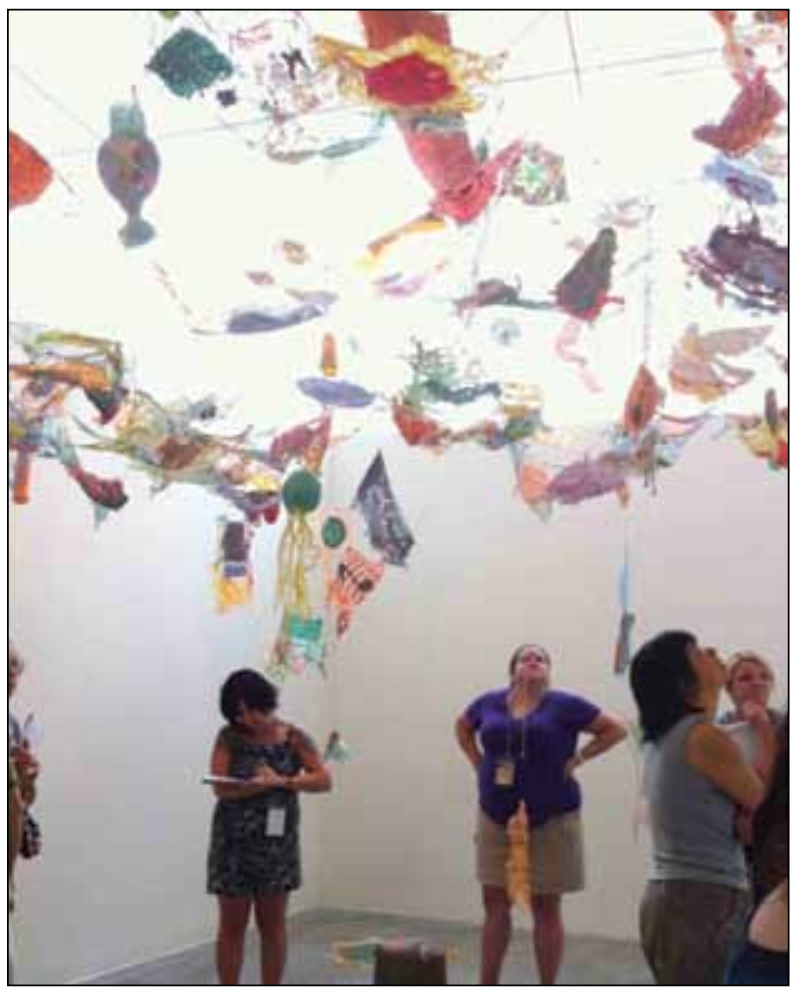

Fig. 6: Takashi Horisaki's latex castings of St. Louis, Missouri 
Mike, a participant and museum-based teacher-leader wrote of the day's experience later on the group's blog:

This first word that comes to my mind as I reflect on the day's experiences is ... DISEQUILIBRIUM. Yes, that word that we all run into in teacher ed courses and ed psych texts, but rarely experience in such a deep, raw way as we may have done today. And not only did we experience the dizzying discomfort of disequilibrium (that's a lot of d's, I realize), but we had a new language and new community with which to dissect the experience, share our personal elements of that experience, and take pieces of it away to build something new later down the road. As I mentioned on Monday, I think there is a certain amount of discomfort needed in order to drive the learning process forward in meaningful and transformative ways.

- Mike, July 10, 2012

Mike's insights remind us of the nature of disequilibrium or discomfort as instructive phenomena, and when we allow ourselves to attend to this state of in-betweenness, we can emerge transformed with insights and visions toward new professional action.

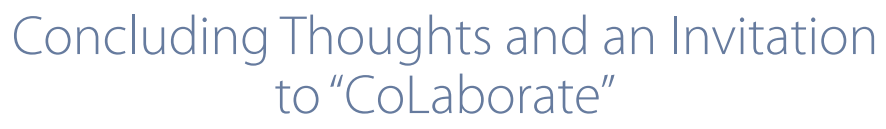

The 3RDspace became a place to explore ResponsiveDesign as a shared theory of action and shared way of exploring diverse cultural landscapes. Group members harnessed cultural practices and technologies to dig into their local vexing problems around the Common Core State Standards, high stakes teacher evaluation concerns facing most United States teachers, and the growing interest for schools to open themselves up to develop partnerships with community-based institutions such as museums. ResponsiveDesign's explore, envision, enact is an iterative and nonlinear process that can yield a logic of inquiry, tailor-made for the user, that guides her/him into a prototyping mindset to rethink ordinary teaching into an extraordinary opportunity for revising and innovating upon failing teaching practices.

When a group of National Writing Project leaders, museum educators, and district literacy coaches develop a shared logic of inquiry as a theory of action, they can harness ResponsiveDesign's prototyping energy to co-explore, co-envision, and co-enact innovations to enhance otherwise sometimes static, prepackaged, and 
lackluster educational cultural practices. This study focused on just one slice of the dynamic and situated nature of how CoLab teacher-researchers convene as a group to inquire into their respective individual challenges, assist each other to take risks into new territories by harnessing design-centric methodologies, and, thus emerge transformed in and through the 3RDspace they individually and collectively created for each other.

We close by inviting you, our future colleagues, to join us as we explore, envision, and enact more 3RDspaces, where we further test ResponsiveDesign's application in formal and semi-formal learning settings in international contexts. Together, we can develop and innovate educational innovations for the benefit of 21 st century learners.

\section{Notes}

1. The Cultural Landscapes Collaboratory (CoLab) is a transdisciplinary community of P-21 teacher-researchers who share a passion and practice for transforming ordinary places into extraordinary creative spaces for professional learning. CoLab emerged over time from the dynamic interplay among teacher-researchers from diverse National Writing Project sites, university-based ethnographic researchers, and museum-based educators.

2. For more information see: http://bit.ly/Xzu6YV.

\section{References}

Achinstein, B., \& Ogawa, R.T. (2006). (In)Fidelity: What the resistance of new teachers reveals about professional principles and prescriptive educational policies. Harvard Educational Review, 76(1), 30-63.

Allington, R.L. (2001). What really matters for struggling readers: Designing researchbased programs. New York: Longman.

Anderson-Levitt, K. (2002). Teaching cultures: Knowledge for teaching first grade in France and the United States. Cresskill, NJ: Hampton.
Anzaldúa, G. (1987). Borderlands: The new mestiza. San Francisco: Spinsters/Aunt Lute.

Anzaldúa, G. (1993). Border arte: Nepántla, el lugar de la frontera. San Diego, CA: Centro cultural de la Raza, 107-114.

Bakhtin, M.M. (1986). The problem of speech genres. In M.M. Bakhtin, Speech genres and other late essays (C. Emerson \& $M$. Holmquist, Eds.; V.W. McGee, Trans; pp. 60-102). Austin: University of Texas Press. 
Córdova, R. (2008). Writing and painting our lives into being: Learning to see learning in the transformative spaces between school and home. Language Arts, 86(1), 18-27.

Córdova, R., \& Matthiesen, A. (2010). Reading, writing and mapping our worlds into being: Shared teacher inquiries into whose literacies count. The Reading Teacher, 63(6), 452-463.

Córdova, R., \& Murawski, M. (2010). Cultural landscapes for literacies learning: An innovative art museum and teacherresearch community partnership. The Missouri Reader, 4(2).

Crocco, M.S., \& Costigan, A.T. (2007). The narrowing of cur- riculum and pedagogy in the age of accountability: Urban educators speak out. Urban Education, 42(6), 512-535. doi:10.1177/0042085907304964

Dana, J. C. (1917). The new museum. Woodstock: Elm Tree Press.

Dewey, J. (1916). Democracy and education: An introduction to the philosophy of education. New York: The Macmillan Company.

Dillon, S. (2006, March 26). Schools cut back subjects to push reading and math. The New York Times, p. 1.

Dixon, C.N., \& Green, J. (2009). How a community of inquiry shapes and is shaped by policies: The Santa Barbara Classroom Discourse Group as a telling case. Language Arts, 86(4), 280-289.

Dyson, A. (1993). Social worlds of children learning to write in an urban primary school. New York: Teachers College Press.

Dyson, A., Bennett, A., Brooks, W., Garcia, J., Howard-McBride, C., Malekzadeh, J. et al. (1995). What difference does difference make? Teacher perspectives on diversity, literacy, and the urban primary school. English Education, 27(2), 77-139.

Fairclough, N. (1992). Intertextuality in critical discourse analysis. Linguistics and Education, 4(3-4), 269-293. doi:10.1016/0898-5898(92)90004-G

Falk, J. H., \& Dierking, J. D. (2000). Learning from museums: Visitor experiences and the making of meaning. Walnut Creek, CA: Altamira Press.
Frake, C.R. (1977). Plying frames can be dangerous: Some reflections on methodology in cognitive anthropology. Quarterly Newsletter of the Institute for Comparative Human Development, 3, 1-7.

Franquíz, M. (1999). Learning in the transformation space: Struggling with powerful ideas. Journal of Classroom Interaction, 34(2), 30-44.

Freire, P. (1998). Pedagogy of the oppressed. New York: Continuum.

Green, J., \& Meyer, L. (1991). The embeddedness of reading in classroom life: Reading as a situated process. In C. Baker \& A. Luke (Eds.), Towards a critical sociology of reading pedagogy (pp. 141-160). Philadelphia: John Benjamins Publishing.

Gumperz, J.J., \& Cook-Gumperz, J. (1986). Interactional sociolinguistics in the study of schooling. In J. Cook-Gumperz (Ed.), The social construction of literacy (pp. 45-68). New York: Cambridge University Press.

Gutierrez, K., Baquedano-López, P., \& Tejeda, C. (1999). Rethinking diversity: Hybridity and hybrid language practices in the third space. Mind, Culture and Activity, 6(4), 286-303.

Heath, S.B. (1983). Ways with words: Language, life, and work in communities and classrooms. New York: Cambridge University Press.

Heathcote, D., \& Bolton, G. (1994). Drama for Learning: Dorothy Heathcote's Mantle of the Expert Approach to Education. Dimensions of Drama Series. HeinemAnne, 361 Hanover St., Portsmouth, NH 03801-3912.

Hein, G. E. (1998). Learning in the museum. London: Routledge.

Hooper-Greenhill, E. (2007). Museums and education: Purpose, pedagogy, performance. London: Routledge.

Ivanic, R. (1994). I is for interpersonal: Discoursal construction of writer identities and the teaching of writing. Linguistics and Education, 6(1), 3-15. doi:10.1016/08985898 (94) 90018-3.

Johnson, S. (2001). Emergence: The connected lives, of ants, brains, cities and software. Scribner. 
Johnson, S. (Ed.). (2011). The innovator's cookbook: Essentials for inventing what is next. New York: Penguin Group.

Kumpulainen., Krokfors, L., Lipponen, L., Tissari, V., Hilppö, J., \& Rajala, A. (2011). Learning Bridges - Toward Participatory Learning Environments. Helsinki: CICERO Learning, University of Helsinki. ISBN 978-952-10-6046-5.

Lave, J., \& Wenger, E. (1991). Situated learning: Legitimate peripheral participation. Cambridge: Cambridge University Press.

MacGillivray, L., Ardell, A.L., Curwen, M.S., \& Palma, J. (2004). Colonized teachers: Examining the implementation of a scripted reading program. Teaching Education, 15(2), 131-144. doi:10.1080/104762 1042000213575

Mitchell, C.J. (1984). Typicality and the case study. In R.F. Ellens (Ed.), Ethnographic research: A guide to general conduct (pp. 238-241). New York: Academic.

Moll, L. C., Amanti, C., Neff, D., \& Gonzalez, N. (1992). Funds of knowledge for teaching: Using a qualitative approach to connect homes and classrooms. Theory Into Practice, 31, 132-141.

Moll, L.C. (1994). Mediating knowledge between home and classrooms. In D. Keller-Cohen (Ed.), Literacy: Interdisciplinary conversations (pp. 139-163). Cresskill, NJ: Hampton.

Montessori, M. (1969). The four planes of development. AMI Communications.

Murawski, M., \& Córdova, R. (2012). Sharing vision and transforming practice, in $B$. Garcia, What we do best: Making the case for the museum learning in its own right. The Journal of Museum Education, 37(2), 47-55.
Santa Barbara Classroom Discourse Group. (1992a). Constructing literacy in classrooms: Literate action as social accomplishment. In H.H. Marshall (Ed.), Redefining student learning: Roots of educational change (pp. 119-150). Norwood, NJ: Ablex.

Santa Barbara Classroom Discourse Group. (1992b). Do you see what we see? The referential and intertextual nature of classroom life. Journal of Classroom Interaction, $27(2), 29-36$.

Santa Barbara Classroom Discourse Group. (1995). Two languages, one community: An examination of educational opportunities. In R. Macias \& R. Garcia (Eds.), Changing schools for changing students: An anthology of research on language minorities, schools and society (pp. 63-106). Santa Barbara, CA: U.C. Linguistic Minority Research Institute.

Souza-Lima, E. (1995). Culture revisited: Vygotsky's ideas in Brazil. Anthropology and Education Quarterly, 26, 443-457.

Spradley, J. (1980). Participant observation. New York: Harcourt Brace.

Turing, A. M. (1952). The Chemical Basis of Morphogenesis Philosophical Transactions of The Royal Society of London. Series B, Biological Sciences, Vol. 237, No. 641.

Wenger, E., McDermott, R., \& Snyder, W.M. (2002). Cultivating communities of practice: A guide to managing knowledge. Harvard Business School Press, Cambridge, USA.

Yeager, E., \& Córdova, R. (2010). How knowledge counts: Families and their lived experiences as resources for academic and social action. In M. Dantas \& P. Manyak (Eds.), Home-School Connections in a Multicultural Society: Learning from and with Culturally and Linguistically Diverse Families (pp. 218-236). Routledge. 


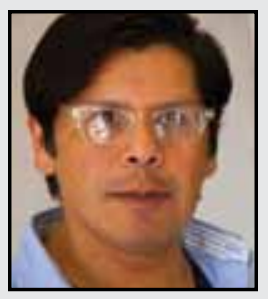

Ralph A. Córdova Jr. is teacher, educational ethnographer, and researcher. A bilingual former 3 rd grade teacher in Santa Barbara, CA, he now teaches at the University of Missouri-Saint Louis. Ralph draws on an interactional ethnographic perspective to conceive of formal learning places like classrooms, and semi-formal places such as museums as cultural landscapes for learning. His areas of expertise are in literacy development, professional development, creativity, and innovation.

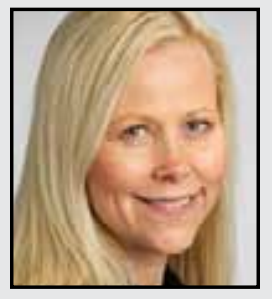

Kristiina Kumpulainen, Ph.D., is a professor of education at the Department of Teacher Education at the University of Helsinki. She specializes in formal and informal learning, learning environments, innovative schools and their pedagogies, teacher professional development as well as undertaking interdisciplinary research for the promotion of learning in the 21st century. Professor Kumpulainen has spearheaded many international research projects examining learning and education from the sociocultural perspective. She has published/co-published over 85 articles and chapters, and delivered more than 100 papers at national and international conferences. She is the chief editor of Life Long Learning in Europe (LLinE) Journal and JETEN, Journal of European Teacher Education Network.

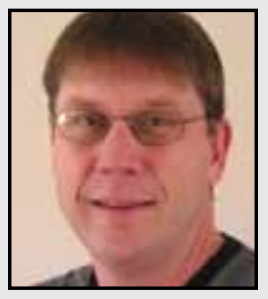

Jeff Hudson has been teaching high school English in Alton, Illinois for the last 17 years. He holds an MA in teaching writing from Southern Illinois University, Edwardsville. He is also a founding fellow and co-director of the Piasa Bluffs Writing Project, a National Writing Project site at SIUE, and a member of the Cultural Landscapes Collaboratory leadership.

\section{LINKTO:}

http://www.OurCoLab.org

http://www.oppimisensillat.fi 